Review paper UDC 1:72(045)

doi: $10.21464 / \mathrm{sp} 33214$

Received: November 21, 2017

\author{
Astrit Salihu \\ University of Pristina, Faculty of Philosophy, Rr. "Nëna Terezë", p.n., XK-10000 Pristina \\ astritsalihu@gmail.com
}

\title{
Odyssey of Dwelling
}

\section{Challenge of Modern Architecture}

\begin{abstract}
The main focus of this article is on philosophical and architectural problems of dwelling. At these junctures, a great debate is again incited regarding the alleged problems in parallel with challenging the standpoints that led to a deadlock which was caused by a modern discourse. A referential figure re-thinking the dwelling outside the framework of modernity is a Norwegian architect and architectural theorist Christian Norberg-Schulz. Inspired by phenomenologists Martin Heidegger and Maurice Merleau-Ponty, Norberg-Schulz will strive to achieve a coherent argument regarding the inseparable link between existence and space; in other words, to settle down an argument about the existential roots of the architectonical space. This premise contests entirely the indifference and arbitrariness of modern architects who remain prone to neglect the fundamental segment of human spatial existence in their works. Having delved deeply into the question of existential and architectonical space and asserting a close connection between the two, Norberg-Schulz developed a widely discussed conception in recent years: the concept of genius loci. By this approach, finally, the self-maintaining discourse of modernity is discarded. The relevance of context, eclectic and recovering of that which is traditional will return from the zero-level of denying the tradition. In this way, the concept of genius loci seems to be highly useful in plain and different architectural definitions, which seem to challenge our existence perpetually. This paper will try to explicate the theoretical consequences on the problems of dwelling, as an essential axis of our Being.
\end{abstract}

\section{Keywords}

modernity, architecture, dwelling, space, existence, genius loci, Christian Norberg-Schulz

The modern ideas are nowhere more tangible than in architecture. Architecture embodies the grand vision and the exhilarated quest for the new - the novum - that marks the modern discourse. However, at the same time, the paradoxes that characterize the modern tenet become peculiarly palpable. Irrespective of numerous proclamations stemming from the distinct fields of modern architecture, aiming to reassess thoroughly the traditional architecture as a whole, they will principally intersect with the ideas propounded by Le Corbusier in his famous book Toward an Architecture. Perhaps the widespread enthusiasm driven by the furious industrial developments, among others, is mirrored in his crucial idea of projecting 'an apartment of an ideal size', a 'dwelling machine', as he would call it later on. In this book, Le Corbusier confirmed the necessity of 'mass production spirit', "the spirit to build mass production houses, to live in mass production buildings, the spirit of conceiving mass production 
houses". ${ }^{1}$ Today, these words sound almost prophetic since the current way of dwelling is grounded in the sequentiality, disfigurement, loss of identity and the dull patterns of the heaps of cages structured in concrete. However, technological advancement was supposed to open up new alternative solutions in the process of construction. Planes, automobiles and trains are being produced in factories - claimed a fascinated Le Corbusier - implying that the same principle could be applied in constructing living spaces.

The elementary existential issue of sheltering-dwelling in the post-World War I period, based on Le Corbusier's view, has already taken place. The unconditional openness toward the future, to what is new and that which is different, perhaps was an epical turning point in the modern consciousness - it is already finding a path in modern architectural discourse, namely, in its utterly rationalised planning of the functionally reduced space of the dwelling. Le Corbusier indicatively pointed out the fact that already 'new age has begun', meaning that "the problem of dwelling is a problem of time. The balance of society depends on it". ${ }^{2}$ The echo of such an attitude will become even larger than Le Corbusier himself could have ever imagined, peculiarly because his position will crucially determine the general orientation of modern architecture, behind which the ideas of demiurge-architects remain hidden. Plans for massive habitations have already been driven by numerous architects. Along with this, Ernst May sets on to construct 15000 apartments in Frankfurt (1929) which will be the reason to call out the Second Congress of the ICMA wherein the main topic will be 'social dwelling'. Perhaps the outcomes of such an approach are still lasting nowadays, whereby no definitive answer for the problem of dwelling is offered yet. The answers given regarding the problems of dwelling will generally exert an important role in architects' reflections throughout the 20th century. Yet, the solutions provided by architects seem to influence the very social core; it affects the entire modern beings' way of life, hence fostering numerous reactions in social and especially philosophical theories. Among the consequences yielding from the great industrial developments, reflected in the modern discourse is the eradication of the individual from its tenacious social ties with the traditional way of life. A continuously increasing diversity and complexity in life organisation confines the free individual, its unrestrained existence and the drifting in the social space. Mass production houses with highly simplified and reduced functions perhaps are the adequate response to the highly required social mobility. The issue of dwelling, among others, will apparently evolve in the most eminent approaches of urbanism, which, at the same time, will be an expression of demiurgic centralization of architects/urbanists that manipulate with space by imposing various policies and strategies of using space as an empty concept.

Lefebvre aptly holds that the issue at hand is imposed from 'above' as "the application of a homogenous and quantitative space, a requirement that 'lived experience' allows itself to be enclosed in boxes, cages or 'dwelling machines". ${ }^{3}$ At these junctures, a great debate is incited again regarding the alleged problems in parallel with challenging the standpoints that led to a deadlock caused by the modern discourse.

\section{Rethinking Dwelling ${ }^{4}$}

Perhaps it is a modern architecture that has taken over the entire process of shaping and organising of our dwelling. However, regardless of the aspiration to contrive approaches that would match daily dwelling needs, much of the 
basic needs and daily vital functions are effectively left out from this projection. As such, modern architectural discourse succumbs to philosophical re-evaluation precisely due to the question of dwelling - for an 'existential space' - which remains perceived by architects solely from a geometrical angle.

Initially, the question of dwelling, which aims to rethink the issue at stake out of already established modernist patterns, is propounded by Heidegger in his well-known lecture "Building, Dwelling, Thinking" held in 1951. This is among the emblematic texts where the issue of dwelling is unfolded in a much broader context than that of a narrowed spacing of the primary and exploitable functions. Almost in parallel, seemingly under the intense concern about this issue, Heidegger held another lecture, "Poetically Man Dwells", wherein the issue of dwelling is explored more deeply.

Heidegger departed from the elementary relationship between building and dwelling by giving primacy to dwelling, because 'we build so that we could dwell and we can dwell'. Thus, a building serves solely as a means to achieve a dwelling. Also, to find the essence of dwelling as such, Heidegger turned attention to the issue of Language itself - recall: Being is Housed in the Language - because Being itself speaks through language. Further, delving deeper into this issue, Heidegger maintained that the dwelling itself is unravelled through language. Interestingly, Heidegger considered the meaning of the German word bauen (build) as related to the root-word buan (inhabit). Thus, according to Heidegger,

“... wherever the word bauen still speaks in its original sense, it tells us to which extent the 'dwelling' matter has reached. Bauen, buen, bhu are in fact the same word as the word bin (am) as in Ich bin, Du bist (I am, you are) and the imperative bis (be)." ${ }^{5}$

Heidegger's stance where dwelling and being are the same to human beings recalls the oblivion of being and reflects the widespread crisis related to the problem of dwelling. Heidegger, therefore, claims that

“... despite how hard and bitter, hampering and threatening the lack of houses remains, the real plight of dwelling does not lie merely in a lack of houses (...) the real dwelling plight lies in this, that mortals ever search anew for the nature of dwelling, that they must ever learn to dwell." 6

Heidegger presses upon the essence of the problem which modern architecture altogether with its demiurge-architects was taking over as its mission, to project our actual way of dwelling. The final sentence of Heidegger's lecture

Le Corbusier, Drejt një arkitekture [Towards New Architecture], translated by Artan Raça, Phoenix, Tiranë 2000, p. 189.

2

Ibid., p. 187.

3

Anri Lefevr [Henri Lefebvre], Urbana revolucija [Urban Revolution], translated by Mirjana Vukmirović-Mihailović, Nolit, Beograd 1974, p. 95.

4

Elements of this chapter were discussed in finer detail in: Astrit Salihu, "Heidegger ili mišljenje arhitekture kroz bitak" ["Heidegger or Thinking Architecture through Being"], Filo- zofska istraživanja 38 (2018) 3, pp. 637-650, doi: https://doi.org/10.21464/fi38313.

5

Martin Heidegger, Leksione dhe Konferenca [Basic Writings], translated by Urim Nerguti, Dritan Thomollari, Plejad, Tiranë 2003, p. 146. Cf. Martin Heidegger, "Building, Dwelling, Thinking", in: Neil Leach (ed.), Rethinking Architecture: A Reader in Cultural Theory, translated by Albert Hofstadter, London - New York, Routledge 2005, pp. 94-119, p. 96.

6

M. Heidegger, Leksione dhe Konferenca, p. 163. 
on dwelling will offer the main guidance for developing an architectural discourse which will radicalise the meaning of existential space. Heidegger's initiation - we point out to the word initiation purposively - somehow recuperates the reflection, thinking of dwelling, wherein thinking was limited and cloaked under the commodity of unerring assumptions on planning principles of modern architects. As such, Heidegger challenges the discourse of modern architecture primary because he conceives the issue of dwelling as indistinguishable from the thinking: 'that they ought to build starting with dwelling, thinking about dwelling'. Thus, the consequences of Heidegger's thought can be easily presumed even though he does not formulate them explicitly.

The highly complex question of dwelling does not solely consist of the alleged identification of dwelling and thinking. Ensuing thinking inspired by Heidegger unfolds other relevant viewpoints on established structures of casual modern living. Lefebvre, for instance, despite his 'reluctance' goes on into a free interpretation drawing a coextensive line between dwelling and the unconsciousness in psychoanalysis. He maintains that perhaps the question of dwelling is suppressed to the degree that we remain in utter ignorance of dwelling. He holds that

“... to find dwelling and its meaning, to actualise it, we have to acquire concepts and categories that are acknowledged through 'the lived experience', towards the unknown and the unrecognised of everyday life - and that also goes way beyond towards general theory, philosophy and metaphilosophy."7

Lefebvre contends that Heidegger's stance is a part of the metaphilosophical approach, as a thought that increases general awareness for modern man's reduced way of dwelling. However, even though critical to Heidegger, it is evident that thinking on dwelling certainly remains the main challenge of modern architecture. The reason is obvious: Heidegger's line of thinking leads us towards the identification of dwelling with tradition, harmony, the security of the situation of a life which grants cohesion and meaning. Meanwhile, life in the modern world is such that foreigners and immigrants offer the model for the experiences of each in modern society, which is mobile or flexible. ${ }^{8}$ This is perhaps the tension where the modern architecture and dwelling stands: that is to say, in finding solutions for the question of dwelling out of the peculiar relation with traditional roots.

This tension relying on the very question of dwelling is pointed out also by Heynen, aspiring to ease out the opposing standpoint through an understanding of an 'ambivalence' of modernity itself. Contesting of authentic dwelling from the angle of illusory pretention to restore the harmonious ties with tradition, at the same time, questions the possibility to tie up architectural discourse with any conservative ideology that has given to the respective issue the 'mythical character'. On the other hand, indifference towards the 'empty signs' of the modern project, in which the relation of a human being with space itself remains entirely neglected, is solely another side of the coin, which also inevitably result in reduced oppression of human needs. Exclusionary discourses continue to scrutinize the issue of dwelling, but it seems that the ultimate challenge is to find an alternative pathway in which various amalgamic moments could prevail, preserving a new pluralist age in the architectonical shaping of the spaces we live in today. Perhaps this is the reason why Heidegger's approach furthered by Norberg-Schulz, later on, cannot be considered solely from the perspective of a radical critique of modernity that would finally lead to the eradication of modern discursive premises. Irrespective of how conservative their arguments might seem, revaluation of moder- 
nity is imposed as a necessity altogether with the quest for alternative and attractive solutions which are a demand of time.

\section{Space and Existence}

The great debate, beginning with Heidegger, is continued and advanced by Christian Norberg-Schulz ${ }^{9}$ who expands the understanding of complex structures of spaces where our existence takes place. The evaluation of existential space, which is interrelated with architectonic space, would have to form the 'architectonic totality' that has often been unpretentiously reduced into something that can be modelled-modified differently and tediously.

In his book Existence, Space and Architecture, Norberg-Schulz says that

“... it is understandable that geometry is part of architectonical space syntax, but this has to be integrated in all-encompassing theory (...) we have emphasize the fact that the human envisioning of his space, for his existential space, is impossible to be described relying only on the concepts of geometry circles." 10

Norberg-Schulz's claim unveils a new and different demand from those striving to ideal platonic geometrical shapes of modern architects whereby the fundamental relationship between man and space is entirely missed out. Norberg-Schulz refers to many works of philosophers that have treated the conception of space, starting from Merleau-Ponty's famous work Phenomenology of Perception, Bachelards' Poetics of Space, and Heidegger's standpoint on space treated in the aforementioned lecture, to achieve a coherent argument regarding the inseparable link between existence and space; in other words, to settle down an argument about the existential roots of the architectonical space. This premise contests entirely the indifference and arbitrariness of modern architects who remain prone to neglect the fundamental segment of human spatial existence in their works.

Elaborating the notion of space, or the system of the same, according to Norberg-Schulz, implies the immediate differentiation of five concepts of space: 1) pragmatic space; 2) perceptual space; 3 ) existential space; 4) cognitive space; and 5) abstract space. Norberg-Schulz writes that

“... pragmatic space integrates man with its natural organic environment, perceptual space is fundamental for his identity as a person, existential space engages man into a certain cultural and social totality, cognitive space means man is capable to think about space and, finally, logical space serves as a means to describe all the previous spaces." 11

The identification of existential space which is intrinsically related to the social and cultural totality swiftly reveals the fact that modern architecture is grounded on discarding some of these important premises. As such, for Norberg-Schulz, human spatial existence is intrinsically related to the structure

A. Lefevr [H. Lefebvre], Urbana revolucija [Urban Revolution], p. 95.

8

See: Hilde Heynen, Architecture and Modernity, MIT press, Cambridge 1999, pp. 18-19.

Christian Norberg-Schulz has approached the issue of space and architecture in his books Intentions in Architecture (1963), Existence, Space and Architecture (1971) and Genius
Loci. Toward a Phenomenology of Architecture (1979, English print 1980).

10

Kristijan Norberg-Šulc [Christian NorbergSchulz], Ekzistencija, prostor $i$ arkitektura [Existence, Space and Architecture], GK, Beo$\operatorname{grad} 2006$, p. 20.

11

Ibid., p. 17. 
of existential space as such. To the conception of 'existential space', Norberg-Schulz comes through a psychological conception called 'schemata', propounded by Piaget. As regards 'schemata', Norberg-Schulz argues that

“... space schemata consist of elements that are unchangeable, like basic universal structures (archetypes) and conditioned structures in society or culture and also, lastly, some personal idiosyncrasies. All these, in general, form a 'mirror' of man's environment, respectively a stable system of three-dimensional relations between objects and their different meanings. That is why we unify all the schemata in our concept of existential space."12

Perhaps we could see here how a deeper focus on the analysis of space results in more complex structures related to the basic relationship between man and space, namely, the approach aiming arbitrary modification of space places man into inadequate spatial cadre. Whereas identification of existential roots of space is of particular importance, the abstract-logical or geometrical conception of space remains secondary. Related to this, Norberg-Schulz contends:

“... if we were to interpret the basic presumptions of the psychology of perception in a general sense, then we could say that the basic organising schemata consist of space centres (proximity), paths or streets (continuity), and lands or fields (enclosure). To be oriented, man must primary have such relations, based on which geometrical schemata develops much later to serve some other close purposes." 13

The alleged psychological premises of perception are necessary because they emphasise the elements of existential space, such as centre, path, and domain. Existential space 'gains the real dimension of human existence' only through the combination of an interaction between these elements. Other levels of existential space (geography, landscape, urban level-house, things), which form the totality of existential space, naturally appear based on specific relations between the elements of existential space. Norberg-Schulz claims that

“... levels of existential space represent the structure of space totality, which corresponds to the structure of human existence because man exists about many objects: physical objects, psychological, social and cultural ones." 14

These relations do not emerge simply from spontaneous processes but, as Norberg-Schulz claims, there are several permanent aspects of space relations or 'stable system of place' which, in turn, give identity to the place itself. In this context, it is clear that subtracting substantial elements of the existential space is equivalent to the eradication of the individual from the context of modern social mobility. Current developments in global scale, meanwhile, remain in favour of the alleged mobility. Norberg-Schulz himself is aware of this. He claims that:

“... while the human environment had its structure that responded to existential space thus far (...), today's tendencies seemingly speak in favour of the development of a new movement. Technological communication tools have liberated us from direct human contacts, and evermore people are becoming physically mobile." 15

This is perhaps the natural consequence of the development of contemporary societies, hence the demand for mobility remains somehow always presupposed in the architectonical projects as well. As such, thinking about the antinomy between mobile and stable structures of existential space inevitably imposes a question: does the human demand for stable world in existential space entail retraction from the imposed mobility by current developments? This question perhaps leads to different and various findings which would not have ultimate determination, nor presuppose any final closure, neither on unfounded mobility nor on rooting and confining human within stable struc- 
tures. Norberg-Schulz opposes the 'idea of the mobile world', yet, he diagnoses an important problem on the relationship between man and space. He refers to Lynch's idea that the human environment's function remains that of 'enabling meaningful human mobility'. The issue that has been put forward until recently regarding whether people should live in 'family houses, individual houses or in apartment buildings', is now transformed into the issue from which arises the problem of the human environment and the question of how it can 'become a satisfying part of human existence'. Norberg-Schulz thinks that in the mobile world

“... physical and psychological distances are mixed up, and true identification is being substituted by chaotically taking different stimulants." 16

This occurs because of the lack of the centralised relevance of man as well as due to the inability to identify it with space. To understand Norberg-Schulz's idea, we have to put his entire concept of existential space in direct relation to architectonical space because

"... existential space, as one of the psychological structural elements of the human existence in the world has its real reflection in architectonical space." 17

Norberg-Schulz also thinks that architectonical space is merely the "concretised' existential space. The alleged organic interrelation between existential and architectonical space is seemingly abstracted in numerous modern architectural planning, which puts a man into a disintegrated, unidentifiable whirlwind. The widely proclaimed freedom of modern spatial formation, according to Norberg-Schulz, remains part of a big social disequilibrium. Related to this, he concedes that

“... man in his 'free' arrogance has parted his place and has 'conquered' the world. Yet, he did not achieve true freedom and all that he was left with is hopeless emptiness." 18

The Odyssean motif remains pertinent for Norberg-Schulz, as a figure expressing the tension between freedom and home. Perhaps Adorno and Horkheimer also relate the 'dialectics of enlightenment' to the figure of Odyssey which, as we shall see, is applicable in the very logic of modern architecture as well. Having delved deeply into the question of existential and architectonical space and asserting a close connection between the two, Norberg-Schulz would develop a widely discussed conception in recent years: the concept of genius loci.

\section{Genius loci: Space, Identity, Meaning}

Perhaps the existential roots of space brought up by Heidegger's stance on dwelling led Norberg-Schulz towards sustainable conclusions about the interrelation between existential and architectonical space. All of his theoretical premises find support in Heidegger, peculiarly in the broader phenomeno-

12

Ibid.

13

Ibid., pp. 31-32.

14

Ibid., p. 58.

15

Ibid., p. 63.
16

Ibid., p. 64.

17

Ibid., p. 68.

18

Ibid., p. 64 
logical concept which uncovers the structure of 'being-in-the-world'. Since Norberg-Schulz has already identified the existential roots of space, he paves a path to determine all the flaws in the reductive approach regarding the problem of space and dwelling in modern architecture. When it comes to space, not only logical-mathematical connections are the ones to consider, but also that which 'captures the relation between man and his environment' as a more complex relationship about his identifying and the meaning that it carries for man. In this sense, Norberg-Schulz finds the proper term in the Roman concept of genius loci. For this, he claims that

“... since antiquity, genius loci or the 'spirit of place' is known as a distinct reality which man is submitted to in his daily life. Architecture signifies visualisation of genius loci while an architect's purpose is to create meaningful places that would help man dwell." 19

Architectural planning should not be a product of categorical apparatus of the abstract mind which arbitrarily modifies space, but rather of a specific arrangement of space approached from a contextual perspective. This would avoid the architectural detachment from the context which is planned for the living needs. This enables the recuperation of the authentic and meaningful dwelling and, furthermore, eluding the reduction of dwelling into sheltering. This is precisely because the dwelling itself is more than sheltering. As Norberg-Schulz says, "man dwells when he finds meaning in the environment around him, or simply when being able to experience his environment as meaningful". ${ }^{20}$ Genius loci is an early architectural quality which is completely abstracted in modern architecture. Genius loci is not simply a part of simplistic envisioning of the surrounding environment, but rather a radical effort against the neutralizing of the environment into an utterly manipulating and exploitable space with no specific character at all. As such, NorbergSchulz expounds the structure in which the surrounding environment, and its own character, is manifested. Place is the unit wherein the surrounding environment is reduced. Place is the space where life springs/manifests, wherein the flow of happenings unfolds. Without the conception of place, it is impossible to imagine life of whatsoever event. This is why Norberg-Schulz holds that place is the correct name to explain that which we usually call environment. The striking feature of place is that 'it is a space with its distinguished character'. If we were to define place, according to Norberg-Schulz, then we would find that it is 'something more than an abstract location'. Defining a place would include "a totality made up of concrete things having material substance, shape, texture and colour. Together, these things determine an 'environmental character', which is the essence of place". ${ }^{21}$ Additionally, Norberg-Schulz maintains that place is 'a total phenomenon' which cannot be approached from the reduced aspects of spatial relationships. A place is a qualitative totality, hence abstracting its properties, and a quantitative approach would only lose its character and particularity that it holds for man. This implies that the quantitative approach itself is an abstract approach which presupposes solely a 'spatial dispersing and dimensioning' in a functional sense. Norberg-Schulz claims that "the functional approach left out the place as a concrete 'here', leaving it without particular identity". ${ }^{22}$

This is sufficient for Norberg-Schulz to suggest the orientation of architecture towards phenomenology which is supposed to enable the 'returning to things' to overcome all the shortcomings in modern architecture that remains concerned mostly with the abstract organisation of space. The consequences of modern architecture today are apparent in the uniformity, barrenness and monotony, hence stripped out from their indispensable relationship with place. 
In the analysis of 'today's place', Norberg-Schulz, therefore, points out the symptom of the 'loss of place'. He claims that "most of the modern buildings exist in the 'nowhere'; they do not relate to landscape nor to the coherent and urban entity, but live their own abstract life in a mathematical-technological kind of space". ${ }^{23}$ Inspired by a noble cause to find out an adequate solution for dwelling, modern architecture is perhaps being increasingly detached from its inappropriate, formal and abstract approaches. This is peculiarly palpable after the degradation of ideas of the modern movement in architecture that is widely known as 'vulgar functionalism'. Irrespective of some attractive inhabiting solution in Le Corbusier's Villa Savoye or in Mies Van der Rohe's Tughendhat House, which laid out a new way of living and an acceptable solution was achieved in fulfilling human dwelling and identifying needs. Yet, when 'transferred in the urban realm', the alleged solutions turned out to be differentiated and deficient, inapplicable alternatives to the dwelling. Norberg-Schulz thinks that even Frank Lloyd Wright's demand for an organic architecture was a direct expression of a 'hunger for reality', which was lost completely in the abstract geometrical cleanness of the modern building. He contends that "Wright's approach towards natural phenomena did not consist in the abstract outlook which was common in Europe, but in direct experiencing of archetypal and meaningful "forces". ${ }^{24}$ Certainly, it is necessary to point out the fact that there were other inputs in the modern architectural movement. Also, in modern ideas, there have been sufficient resources to explore and achieve more adequate and more acceptable solutions. Although it is impossible to speak for, so to say, linear development of modern architecture, yet functionalism and rationalism were mostly implemented which led to the general crisis being diagnosed today. Norberg-Schulz perhaps will reduce the entire crisis of modern architecture precisely into the alleged abstracting of place. He explicitly maintains that the problems of modern architecture stand in 'deficient grasping of the notion of place' as well as the architecture's uniformed stand in the architectonical expression of that which is known as 'international style'. Only by turning to place, only through the theory about a place can we avoid all the problems that modern architecture is facing today. Solely by returning to the place, only through a theory of place, one can cope with the respective problems of modern architecture. Norberg-Schulz writes that

“... place theory not only integrates different contributions and offers a summarized concept on the relationship between man and his environment, but it also shows that the history of modern architecture has a direction and an aim: architecture as a recovery of place (...) moreover the concept of place connects modern architecture to the past." 25

Thus, Norberg-Schulz's ambition is returning toward contextualism and, at the same time, the explicit contestation of conceptualism. These two approaches

19

Christian Norberg-Schulz, Genius Loci, Towards a Phenomenology of Architecture, Rizzoli, New York 1980, p. 5.

20

Ibid.

21

Ibid., pp. 6-7.

22

Ibid., p. 8 .
23

Ibid., p. 190.

24

Ibid., p. 192.

25

Ibid., p. 201. 
describe the paradigmatic element of two different and distinct discourses that are widely known as the modern and the postmodern. This tension is apparent in architecture as well; revising the modern discourse in architecture is developed precisely within this paradigmatic shift from concept towards context. Moreover, Norberg-Schulz considers his theory sustained in genius loci as the final expression regarding the course that modern architecture is taking with its turning towards 'regionalism'. He contends that the 'third generation' of modern architects is heading toward reinstating the lost connections between place and architectonical planning. However, this twist, for him, is not simply a protest against or withdrawal from modern discourse; hence he still holds a critical distance. He claims that

“... the new regionalism is indeed a reaction towards vulgar technocratic functionalism, but above all, it represents the natural course of development of the modern. By the concept of genius loci, I attempt to assure the theoretical grounds for such an aim. Originally this meant an escape from abstractions which are alien to life and from the wasted stimulants of today's world so that we can return to things." 26

Attentive analysis of place and environment in architecture is a necessary condition in bringing back the meaningful dwelling of man who is lost in the defaced urbanism created after the 'destruction of traditional urban forms'. ${ }^{27}$ Adopting concrete and substantial elements in architectural planning seems to be a necessary condition in returning the identity and character of our dwelling space. In this sense, he maintains that

“... the returning to things in architecture means once again talking about landscape, the exterior and articulation. These are not shapes, ordinary shapes, but meaningfully moulded things, human world elements, so to speak." 28

Norberg-Schulz's standpoint is that wherein the notion of genius loci is peculiarly considered, it contains a nostalgic intonation for the lost harmony and warmth in man's traditional way of living. Although well-elaborated, in the course of the coherent argumentation for the need to consider man's meaningful dwelling, Norberg-Schulz's views often challenge the real implementing possibilities because of the society's current mobility process. It is not a coincidence that his disagreement with increasing societal mobility, numerous interpreters understood his standpoint to be an effort to confine man within stable structure which has always been associated with violent totalitarian societies. ${ }^{29}$ When it comes to the tension between rootedness and freedom of man, for instance, Norberg-Schulz is in favour of man's rootedness because he considers that mobility, moving, and incapability to identify with place brings man towards imbalance and estrangement - an existence stripped of meaning.

Apart from numerous reluctant implications regarding modern discourse, there are various elements to be attained in advancing man's current living ways aiming to find meaningful elements for his existence. This, of course, implies the need to find out a third option, a still undefined path, but the one which is still being explored in the current research on architecture.

This primarily means that one should avoid one-sided commitments to both radical modernism and radical anti-modernism. Adopting modern radical premises could lead towards the loss of dwelling itself, loss of the meaning and loss of man's identity, which results in various deficiencies and with people's general deprivation in defaced suburbs of many cities where the modern plans have been implemented. On the other hand, the aim to bring back 'the spirit of place', tradition and stable confined structures of dwelling are all out of context of the time we live in and based on which society functions today. 
Thus, this is still a disputable issue and an on-going debate on the current directions of the architecture, namely, for its orientation toward regionalism, context and tradition. However, the question herein is whether this is a mere revision of modern architecture or is it a paradigmatic shift toward postmodern architectural discourse? Given elements that are constitutive of modern discourse, it seems to be more a paradigmatic shift, a great shift perhaps, toward what is known as the postmodern architecture. By this approach, finally, the self-maintaining discourse of modernity is discarded. Namely, the relevance of context, eclectic and recovering of that which is traditional will return from the zero-level of denying the tradition. In this way, the concept of genius loci seems to be highly useful in plain and different architectural definitions, which seem to challenge our existence perpetually.

\title{
Astrit Salihu \\ Odiseja obitavanja \\ Izazovi suvremene arhitekture
}

\begin{abstract}
Sažetak
Glavni je fokus ovog članka problem stanovanja u filozofiji i arhitekturi. U problemu stvorenom ovim načinom nametanja objašnjenja stanovanja u modernizmu, započeta je velika debata gdje se iznova promišlja stanovanje kao relevantno pitanje za stvorene probleme i istovremeno kao neposredan način izazova mogućim alternativama izlaženja iz zastoja do kojih je dovela moderna sa svojim idejama i vizijama. Glavna figura novog promišljanja arhitekture izvan modernističkih shema norveški je arhitekt Christian Norberg-Schulz. Inspiriran Martinom Heideggerom i Mauriceom Merleau-Pontyjem, pokušat će postići koherentnu argumentaciju o narazdvojivosti prostora i egzistencije, ili o egzistencijalnom korijenu arhitektonskog prostora. Pretpostavka ove teze kontestira indiferenciju i svojevoljnost modernih arhitekata, koji samoutemeljuju arhitektonsku projekciju izostavljajući fundamentalni segment prostorne egzistencije čovjeka. Udubljivanjem u problematiku egzistencijalnog $i$ arhitektonskog prostora, evidentiranjem tijesnog nadovezivanja među njima, Norberg-Schulz će razviti jedan, ne malo diskutirani pojam: pojam genius loci. Njegovim će se pristupom napokon apstinirati od samoutemeljenja moderne, $i$ od njene nulte premise odbacivanja tradicije u kojoj će se povratiti kontekst, eklekticizam i rehabilitacija tradicionalnog. Na ovom putu pojam genius loci nameće se kao potpomažući u jasnom i drugačijem definiranju arhitekture koja je u stalnom izazovu naše egzistencije. Ovaj članak pokušava eksplicirati teorijsku konzekvencu problema stanovanja, kao osi našeg bitka.
\end{abstract}

\section{Ključne riječi}

moderna, arhitektura, stanovanje, prostor, egzistencija, genius loci, Christian Norberg-Schulz

Christian Norberg-Schulz, "Genius Loci", Lotus International 13 (1976), pp. 57-67; cf Miloš Perović, Antologija. Teorija arhitekture $X X$ veka [Anthology. Theory of architecture in 20th century], GK, Beograd 2009, p. 569.

27

M. Perović, Antologija, p. 562 [NorbergSchulz].
28

M. Perović, Antologija, p. 569 [NorbergSchulz]

29

H. Heynen, Architecture and modernity, pp. 22-24. 


\section{Astrit Salihu}

\section{Odyssee des Wohnens}

\section{Herausforderungen der zeitgenössischen Architektur}

\section{Zusammenfassung}

Der Hauptfokus dieses Artikels ist das Problem des Wohnens in Philosophie und Architektur. In dem Problem, das durch diese Art der Erklärungsaufdrängung bezüglich des Wohnens im Modernismus geschaffen wird, hat eine große Debatte begonnen, in der aufs Neue über das Wohnen reflektiert wird, und zwar als relevantes Thema für die geschaffenen Probleme und zugleich als eine unmittelbare Art der Herausforderung an die möglichen Alternativen, aus dem Stillstand herauszukommen, zu denen die Moderne mit ihren Ideen und Visionen geführt hat. Die Hauptfigur der neuen Reflexion über die Architektur außerhalb der modernistischen Schemata ist der norwegische Architekt Christian Norberg-Schulz, inspiriert von Martin Heidegger und Maurice Merleau-Ponty; er wird versuchen, zu einer kohärenten Argumentation über die Untrennbarkeit von Raum und Existenz oder über die existenzielle Wurzel des architektonischen Raums zu gelangen. Die Annahme dieser These kontestiert die Indifferenz und Eigenwilligkeit moderner Architekten, die die architektonische Projektion selbst fundieren, indem sie das fundamentale Segment der räumlichen Existenz des Menschen ausblenden. Durch die Vertiefung in die Problematik des existenziellen und architektonischen Raums und die Evidentierung der engen Anknüpfung zwischen ihnen wird Norberg-Schulz einen nicht unterdiskutierten Begriff entwickeln: den Begriff des genius loci. Durch seinen Ansatz wird man letztendlich von der Selbstgründung der Moderne ablassen, wie auch von deren Ausgangsprämisse der Zurückweisung der Tradition, in der der Kontext, der Eklektizismus und die Rehabilitation des Traditionellen wiederhergestellt werden. Auf diesem Weg zwingt sich der Begriff des genius loci als Unterstützung einer klaren und andersartigen Definition der Architektur auf, die sich in der ständigen Herausforderung unserer Existenz befindet. Dieser Artikel versucht, die theoretische Konsequenz um das Problem des Wohnens als Achse unseres Seins zu explizieren.

Schlüsselwörter

Moderne, Architektur, Wohnen, Raum, Existenz, genius loci, Christian Norberg-Schulz

\section{Astrit Salihu}

\section{L'odyssée du logement}

\section{Les défis de l'architecture contemporaine}

\section{Résume}

Cet article porte essentiellement sur le problème du logement vu par la philosophie et l'architecture. À partir de ce problème, créé par une certaine façon d'imposer l'explication du logement à l'époque moderne, un grand débat est né au sein duquel le logement est repensé en tant que question pertinente pour les problèmes créés, et en même temps, en tant que manière directe pour lancer des défis aux possible alternatives qui visent à remédier au point mort entraîné par les visions et les idées de l'époque moderne. L'architecte norvégien Christian Norberg-Schulz, inspiré par Martin Heidegger et Maurice Merleau-Ponty, est la figure principale de cette nouvelle manière de penser qui s'éloigne des schémas modernes. Norberg-Schulz tentera d'aboutir à une argumentation cohérente sur l'inséparabilité de l'espace et de l'existence, ou encore, sur la racine existentielle de l'espace architectonique. L'hypothèse de cette thèse conteste l'indifférence et l'arbitraire des architectes modernes dont le travail se résume à fonder un projet architectonique, ne prenant pas en considération le segment fondamental de l'existence spatiale de l'homme. En approfondissant la problématique de l'espace existentiel et architectonique et en relevant le lien étroit entre eux, Norberg-Schulz développera un concept, qui sera néanmoins discuté : le concept de genius loci. C'est à la suite de son approche qu'on évitera les principes de base réducteurs de l'époque moderne et de ses prémisses inexistantes qui rejettent la tradition au sein de laquelle va s'opérer un retour du contexte, de l'éclectisme et de la réhabilitation du traditionnel. Sur ce chemin, le concept de genius loci s'impose comme un concept qui contribue de manière claire et différente à définir une architecture, qui de manière continu, défie notre existence. Cet article tente d'expliquer la conséquence théorique du problème du logement, en tant qu'axe de notre être.

Mots-clés

époque moderne, architecture, logement, espace, existence, genius loci, Christian Norberg-Schulz 